Review

\title{
Eco-efficient construction and building materials research under the EU Framework Programme Horizon 2020
}

\author{
F. Pacheco-Torgal \\ C-TAC, Sustainable Construction Group, University of Minho, Portugal
}

\section{H I G H L I G H T S}

- Horizon 2020 constitutes the most important instrument for research and innovation in the world.

- Horizon 2020 sustainability focus will have a strong impact on the European construction industry.

- Development of eco-efficient building materials fits well on the Horizon 2020 targets.

- Nanotech energy efficiency building materials can constitute a crucial Key Enabling Technology-KET.

\section{A R T I C L E I N F O}

\section{Article history:}

Received 13 August 2013

Received in revised form 10 October 2013

Accepted 31 October 2013

\section{Keywords:}

Resource efficiency

Energy efficiency

Waste recycling

KETs

Nanotechnology

\begin{abstract}
A B S T R A C T
With an overall budget of around 70,000 million $€$ for the next seven years (2014-2020) the EU Framework Programme for research and Innovation-Horizon 2020 constitutes the most important financial instrument for research and innovation in the world. Sustainable development is of paramount significance for Horizon 2020 through climate action and resource efficiency, which will represent at least $60 \%$ of the overall budget. This sustainability focus could have a strong impact on the future of the European construction industry and also being an opportunity for the development and commercialization of eco-efficient construction and building materials. This article addresses the case of materials for energy efficiency and materials capable of reusing a high waste content. Nanotech energy efficiency related building materials has the potential to become a hot research area being promoted and funded as a Key Enabling Technology-KET.
\end{abstract}

(c) 2013 Elsevier Ltd. All rights reserved.

\section{Contents}

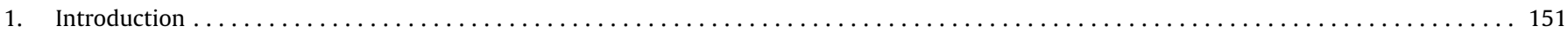

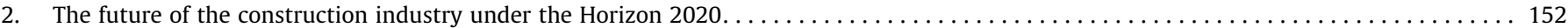

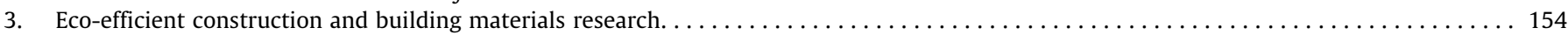

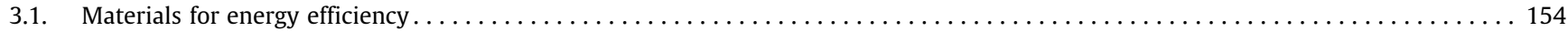

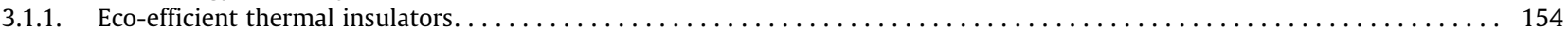

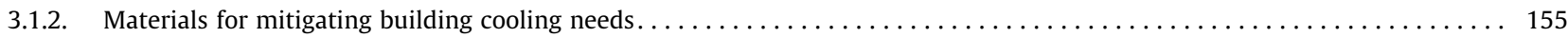

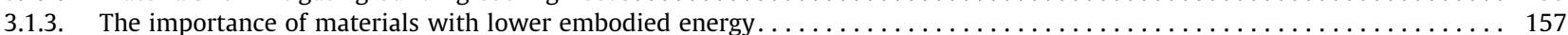

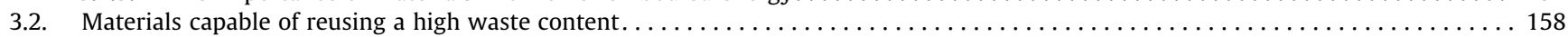

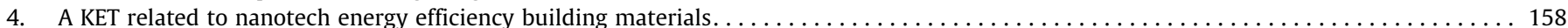

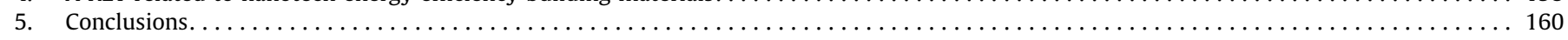

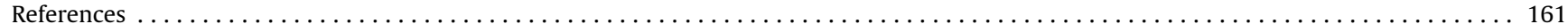

\section{Introduction}

The program Horizon 2020 is part of the Europe 2020 strategy to promote smart, sustainable and inclusive growth [1]. The Horizon 2020 was originally designed by the European Commission in

E-mail addresses: torgal@civil.uminho.pt, f.pachecotorgal@gmail.com
November of 2011 [2] with a $€ 80,000$ million overall budget. However, a "trilogue" agreement was reached only in 25 of June of 2013 (including a cut of $€ 10,000$ million) by the representatives of the Council, the Commission and the Parliament. Horizon 2020 constitutes the most important financial instrument for research and innovation in the world and is expected that to jump start the creation of up to 50,000 new jobs in research and 
innovation. However, it is important to mention that even though this program attributes more 14,400 million $€$ than the previous Seventh Framework Programme (FP7), the first and second years of Horizon 2020 will have a lower budget than the last year of FP7 (Fig. 1). Horizon 2020 will consist of three main parts, or pillars:

(1) Excellent science. This will support the best ideas and the most talented and creative individuals. It will provide access to world-class research infrastructures (including e-infrastructures) allowing Europe to attract the best researchers in the world. This area includes the European Research Council-ERC with a $17 \%$ share of the overall budget, emerging technologies, Marie Curie actions and research infrastructures. It is important to mention that the bet on excellent science is a consequence of the 1994 debate on the "European paradox" $[4,5]$ related to the fact that for many years the high scientific production in Europe was unable to bring innovation, growth and jobs.

(2) Industrial leadership. This part is aimed at maximizing the growth potential of European SMÉs so they may become world leading companies. It will provide major investments in industrial technologies, innovation in SMEs and access to risk finance. It also includes leadership in Key Enabling Technologies (KETs).

(3) Societal challenges. This pillar addresses major concerns shared by citizens in Europe and elsewhere covering the following challenges:

- Health, demographic change and wellbeing.

- Food security, sustainable agriculture, marine and maritime research.

- Bio-economy.

- Secure, clean and efficient energy.

- Smart, green and integrated transport.

- Climate action, resource efficiency and raw materials.

- Inclusive, innovative and secure societies.

The overall budget of Horizon 2020 also includes the funding of the European Institute of technology (EIT). The EIT budget will increase from 309 million $€(0.6 \%$ of FP7) to 2500 million $€$ representing around 3.3\% of Horizon 2020. The funding of the Joint Centre of Research (JCR) and the EUROATOM is also included. Fig. 2 shows the percentage division under the initial budget proposal. However, the 2013 June "trilogue"agreement reduced the societal challenges percentage to $38 \%$ and increased the excellent science percentage to $37 \%$. Meanwhile, KETs are to receive $€ 6663$ million. Horizon 2020 dedicates a special attention to sustainable development, trough climate action and resource efficiency that will represent at least $60 \%$ of the overall budget. It is expected that around
$35 \%$ of the Horizon 2020 budget will be climate related expenditure.

\section{The future of the construction industry under the Horizon 2020}

This is a major European industry, representing 9.1\% of the EU27 GDP, 30.2\% of the EU-27 industrial employment and having a $€$ 82,300 million annual turnover [6]. Unfortunately this industry tends to lag behind other industries in terms of taking advantage of new technologies and innovative practices [7]. Hopefully the sustainability concerns of Horizon 2020 (resource efficiency and climate action) will have a strong impact on the future of the European construction industry. Indeed, the influence of resource efficiency on building sector is clearly expressed by the milestone below included in the COM 571 [8]:

"By 2020 the renovation and construction of buildings and infrastructure will be made to high resource efficiency levels. The Lifecycle approach will be widely applied; all new buildings will be nearly zero-energy and highly material efficient and policies for renovating the existing building stock will be in place so that it is cost-efficiently refurbished at a rate of $2 \%$ per year. $70 \%$ of nonhazardous construction and demolition waste will be recycled".

Concerning climate action, it can be anticipated that it will determine the future actions on the construction sector. In fact, current and future infrastructures will need to be adapted to natural disasters including floods, windstorms, droughts, fires, heat and cold waves, sea level rise and even landslides. Fig. 3 shows some of the impacts of climate change and the threats they pose in the coming decades. The rapid increase of river floods and excessive hot days for the next decades is very worrying. That is why the words of the European Commissioner for Climate Action, Connie Hedegaard, on the launch of the EU Strategy on

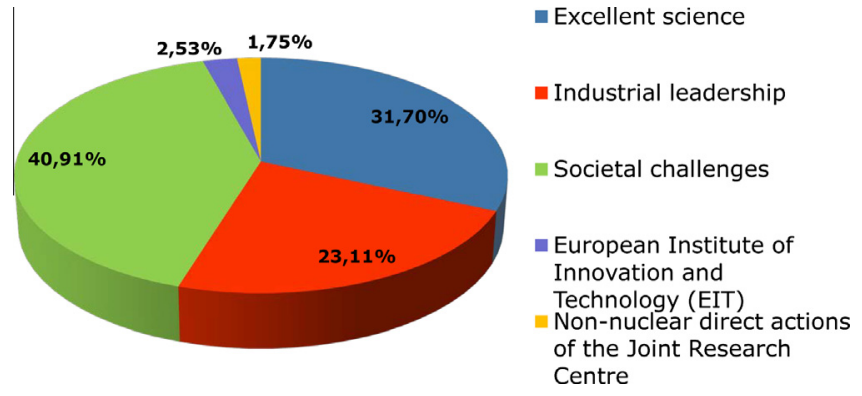

Fig. 2. Percentage division under the initial budget proposal of Horizon 2020.

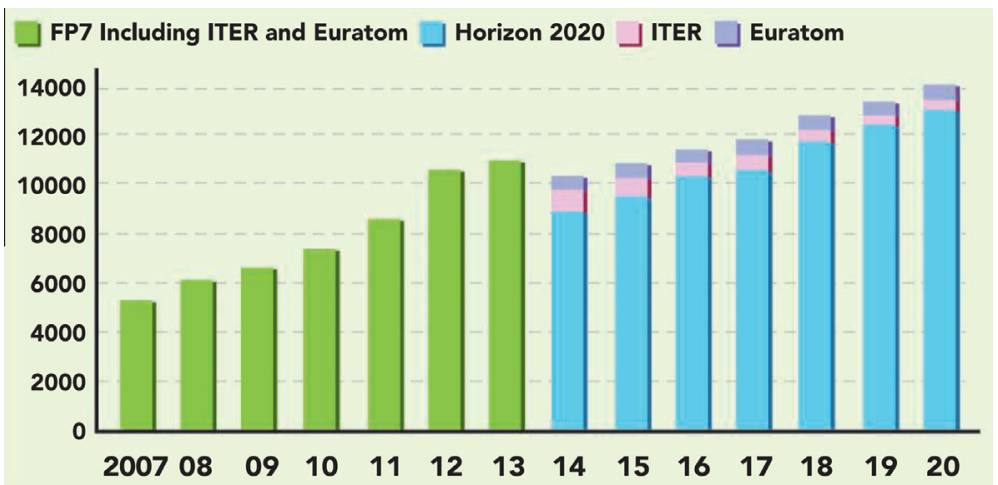

Fig. 1. Annual funding comparison between FP7 and Horizon 2020 [3]. 
Adaptation to Climate Change in Brussels, in 29 April of 2013 make a lot of sense: "Investing now in adaptation will save lives and much greater costs later!". This means that the overall objective of the EU strategy on adaptation to climate change is to contribute to a more climate-resilient Europe. According to the COM 216 [10] "the minimum cost of not adapting to climate change in the $E U$ is estimated to range from $€ 100$ billion a year in 2020 to $€$ 250 billion in 2050". The social cost of climate change can also be significant. Taking no further adaptation measures could mean an additional 26,000 deaths/year from heat waves (and their synergic effects with air pollution) by the 2020 s, rising to 89,000 deaths/year by the 2050s and 127,000 deaths/year by the 2080s. It is worth to mention that the consequences due to heat waves prediction do not take into account the effect associated with heat islands in urban environments, where $70 \%$ of the European population lives. This means this aspect in particular deserves an appropriate response. The future of the European construction industry under Horizon 2020 will therefore involve the adaptation of current and future infrastructure towards climate-resilience. The document SWD 137 [11] details some measures for adapting several infrastructure types to climate change. Concerning the construction sector they are as follows:
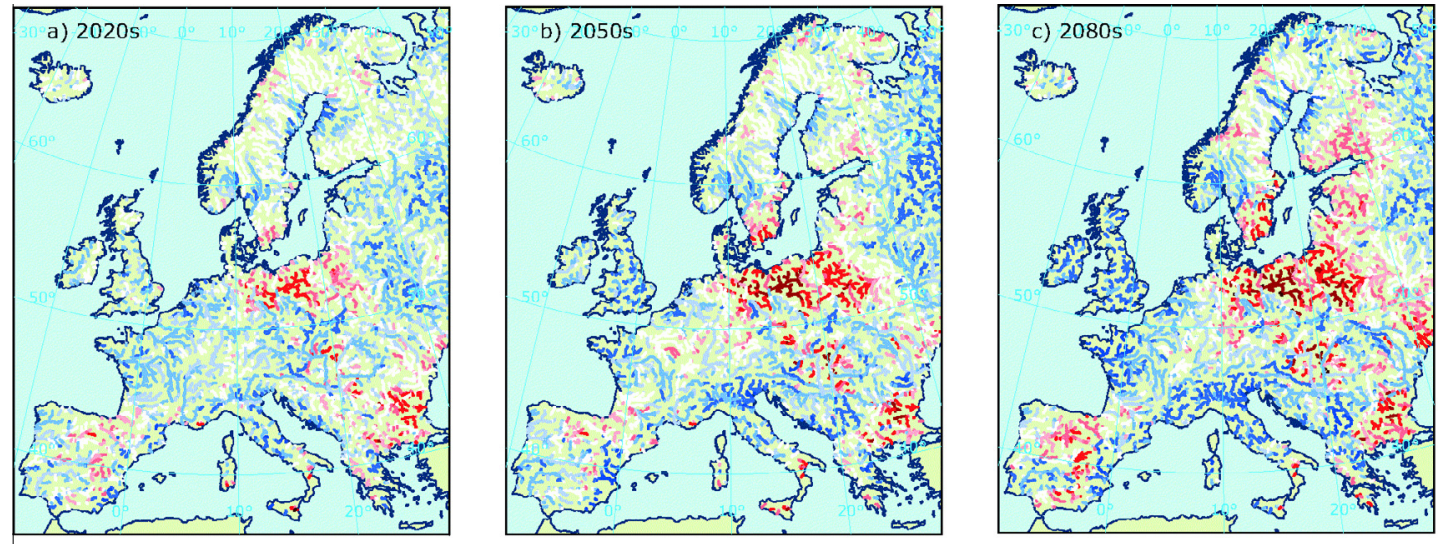

Relative change in river floods with a return period of 100 years between future period and 1961-1990 (SRES A1B)

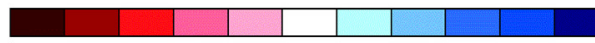

(\%) $-60-40-20-10-5 \quad 5 \quad 10 \quad 20 \quad 40 \quad 60$

(c) 2012 JRC, European Commission
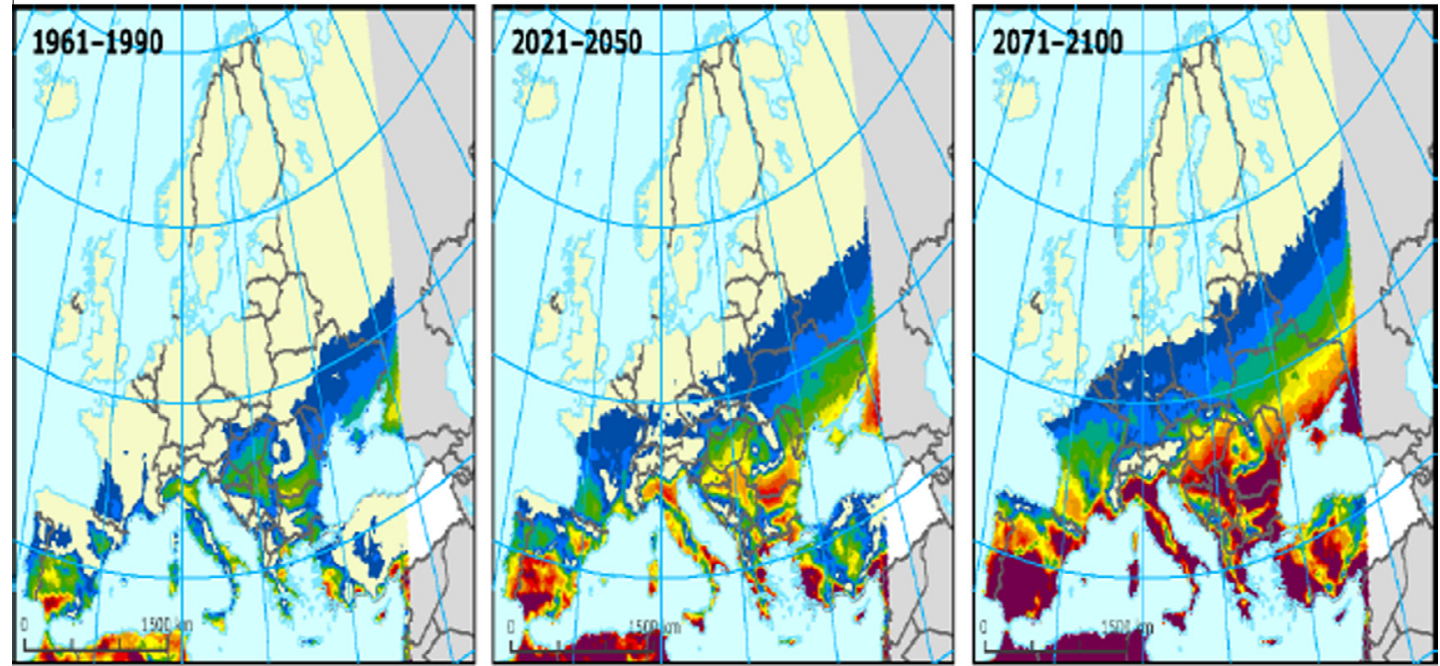

Number of combined tropical nights $\left(>20^{\circ} \mathrm{C}\right)$ and hot days $\left(>35^{\circ} \mathrm{C}\right)$

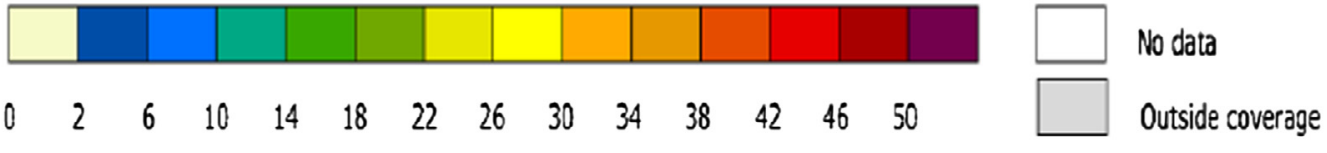

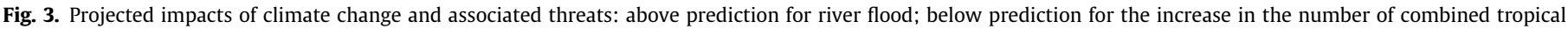
nights and hot days [9]. 
(1) Extreme precipitation, which can be expected European wide, e.g. leading to water intrusion, damage to foundations and basements, destruction of buildings and infrastructure, overflowing sewers, land- and mud-slides, flooding, etc.

(2) Extreme summer heat events, especially but not only in South Europe, e.g. leading to material fatigue and accelerated aging, decreased comfort and potentially severe health implications, high energy use for cooling, et cetera.

(3) Exposure of constructions to heavy snowfall.

(4) Rising sea levels that increase the risk of flooding. In addition, soil subsidence risks 25 are likely to increase, depending on the stability of building structures and their foundations.

Giordano [12] points out that many existing and planned infrastructures (Table 1) will still be in use by 2030 or 2050 when climate change might have far more substantial impacts than today. Besides, since vulnerability to natural disasters is one of the world biggest problems [13] and as, according to OECD [14], global infrastructure needs are huge, and also being that improving the world's infrastructure will require an estimated USD 2 trillion/ year (other authors [15] mention 6, 7 trillion/year) this means that the European construction industry can use Horizon opportunities in order to become world competitive in the climate-resilient area. It is worth to mention that the opportunities for adapting infrastructures to the impact of climate change are already being pursued by the UK [16] as the Secretary of State for Environment, Food and Rural Affairs, recognizes "UK leading infrastructure operators. . .can capitalise on global adaptation. . .to gain a competitive edge in. . world markets". This, of course, is based on the assumption that enough civil engineers exist, and more importantly, they have the appropriate skills. Unfortunately it seems that this is hardly the case because in the last decade several authors reported a severe reduction on undergraduate applications to civil engineering [17-19]. Hopefully academia will help the construction industry on this matter by seizing Horizon 2020 opportunities and climate resilience infrastructure needs to refresh and update civil engineering courses in order to tackle the reduction in the enrollment ratio in this sector.

\section{Eco-efficient construction and building materials research}

Under the sustainable development concerns of Horizon 2020 some construction and building materials research lines will merit a special attention. These areas include the following:

Table 1

Long lived infrastructure and their vulnerability to climate change [12].

\begin{tabular}{lll}
\hline Sectors & Time scale (years) & Exposure \\
\hline $\begin{array}{l}\text { Economic and social buildings } \\
\text { (e.g. factories, schools, hospitals) }\end{array}$ & $>20$ & + \\
$\begin{array}{l}\text { Water infrastructures (e.g. dams, } \\
\text { reservoirs, distribution networks) }\end{array}$ & $20-300$ & +++ \\
$\begin{array}{l}\text { Land-use planning (e.g. in flood } \\
\text { plain or coastal areas) }\end{array}$ & $>100$ & +++ \\
$\begin{array}{l}\text { Coastline and flood defenses } \\
\text { (e.g. dikes, sea walls) }\end{array}$ & $>50$ & +++ \\
$\begin{array}{l}\text { Buildings (e.g. insulation, windows) } \\
\text { Transportation infrastructure } \\
\text { (e.g. port, bridges, roads, }\end{array}$ & $30-150$ & ++ \\
$\begin{array}{l}\text { railways, train stations) } \\
\text { Urban forms (e.g. urban } \\
\text { density, parks) }\end{array}$ & $30-200$ & + \\
$\begin{array}{l}\text { Energy production and } \\
\text { transportation (e.g. power } \\
\text { plants, cooling system, } \\
\text { distribution network) }\end{array}$ & $>100$ & + \\
\hline
\end{tabular}

\subsection{Materials for energy efficiency}

In Europe buildings are responsible for more than $40 \%$ of the energy consumption and greenhouse gas emissions [20] thus increasing building energy efficiency is crucial for the transformation of the UE energetic framework [21]. Energy efficiency is the most cost effective way to reduce emissions, improve competitiveness and create employment. COM 815 [22] mentions that the Union's energy efficiency target of saving $20 \%$ of energy by 2020 could cut consumers' bills by up to $€ 1000$ per household a year and improving Europe's industrial competitiveness and creating up to 2 million new jobs by 2020. In spite of that the EU recognizes that "The quality of National Energy Efficiency Action Plans, developed by Member States since 2008, is disappointing, leaving vast potential untapped" [23]. The European Energy Performance of Buildings Directive 2002/91/EC (EPBD) has been recast in the form of the 2010/31/ EU by the European Parliament on 19 May 2010 [24]. One of the new aspects of the EPBD is the introduction of the concept of nearly zero-energy building (NZEB). This represents an ambitious target that must be multidisciplinary approached [25]. Of all the new aspects set out by the new directive this one seems to be the one with most difficult enforcement by Member states. The article 9 of the European Directive establishes that, by the 31 st of December of 2020, all new constructions have to be nearly zero-energy buildings; for public buildings, the deadline is even sooner - the end of 2018. This very ambitious target would be more easily fulfilled if eco-efficient thermal insulators are to be used.

\subsubsection{Eco-efficient thermal insulators}

The use of thermal insulation materials constitutes the most effective way of reducing heat losses in buildings thus reducing heat energy needs. These materials have a thermal conductivity factor, $k(\mathrm{~W} / \mathrm{m} \mathrm{K})$ lower than 0.065 and a thermal resistance higher than $0.30\left(\mathrm{~m}^{2} \mathrm{~K}\right) / \mathrm{W}$. Traditional thermal insulation materials include the following ones:

- Expanded polystyrene.

- Mineral wool.

- Extruded polystyrene.

- Expanded chipboard cork.

- Rigid foam of poly-isocyanurate or polyurethane.

With the exception of expanded cork, which is based on a renewable and completely recyclable material, all the other insulation materials are associated with negative impacts in terms of toxicity. Polystyrene, for example contains anti-oxidant additives and ignition retardants, additionally, its production envolves the generation of benzene and chlorofluorocarbons. On the other hand, polyurethane is obtained from isocyanates, which are widely known for their tragic association with the Bhopal disaster [26]. Besides, it releases toxic fumes when subjected to fire [26,27]. In recent years some investigations have focused on thermal insulation materials based on natural materials like hemp fibres [28]. Although thermal insulation materials based on flax and hemp fibres show high insulation performance, these fibres are less costeffective than glass or mineral fibres [29]. Still natural insulation materials require low manufacture energy and they can be easily disposed of at the end of their life cycle by composting or by recovering their calorific value in a furnace [30]. These are all important advantages that merit their use as insulation materials justifying recent research efforts on this field [31-33]. Finally, the assessment of the natural based insulation materials life cycle is of special interest [34].

The need to reduce energy costs in buildings, meant that the thickness of thermal insulation materials has grown over the years. 
In fact, in some countries of Northern Europe, it has almost doubled (Fig. 4). The development of high performance thermal insulator materials (with low thickness) has become a technical challenge that the scientific community has had to deal with. At first, the solution involved the development of panels containing rare gases; however it soon became evident that their performance was surpassed by vacuum insulation panels (VIPs) which provide a thermal insulation almost ten times that of current thermal insulation materials. VIPs consist of a core material (which is placed inside the vacuum panel) of much lower thickness for the same thermal performance. Although the initial applications used polystyrene core, lately they have been replaced by fumed silica submitted to a compression of up to $200 \mathrm{~kg} / \mathrm{m}^{3}$, a procedure that causes the air pores to a pressure below the atmospheric pressure [36]. Some disadvantages of VIPs are the fact that they cannot be cut on-site, its fragility is associated with the risk of being easily damaged, and also, the fact that its use can be associated to thermal bridging effects $[37,38]$.

\subsubsection{Materials for mitigating building cooling needs}

Building cooling needs have increased in an exponential trend in the last two decades going from 6 TJ in 1990 to 160 TJ in 2010 [39]. According to Crawley, "the impact of climate change will result in a shift from heating energy to cooling energy for buildings in temperate climates" [40]. Other authors mention that depending on the climate zone cooling loads are likely to increase by 50 to over $90 \%$ until the end of the century [41]. Since urban population will increase in the next decades building cooling needs due to urban heat island effect will also increase [42]. The synergistic effect between heat waves and air pollution causes worse outdoor air quality in the summer and will prevent natural ventilation thus aggravating cooling needs. Therefore, it is important that new eco-efficient materials and technologies are developed capable of mitigating building cooling needs. Recent investigations on this field include the following:

3.1.2.1. Reflective pavements. These pavements are mainly based on the use of surfaces presenting a high albedo to solar radiation (albedo is a dimensionless fraction and is measured on a scale from 0 to 1 . An albedo of 0 means no reflecting power of a perfectly black surface, an albedo of 1 means perfect reflection of a perfectly white surface) combined with a high thermal emissivity [43]. Table 2 presents the description of the existing technological trends on the field of reflective pavements.
3.1.2.2. Permeable and water retentive pavements. These pavements are designed to allow water to drain through into the sublayers and down into the ground. They may include water holding fillers to store water so the evaporation can help to decrease surface temperature. These pavements are not meant for high-speed traffic. Table 3 presents a description of the existing technological trends on the field of permeable and water retentive pavements. Other non-conventional permeable pavements include vegetated permeable pavements, such as grass pavers and concrete grid pavers, that use plastic, metal, or concrete lattices for support and allow grass or other vegetation to grow in the interstices [44].

3.1.2.3. Passive evaporative cooling walls. Evaporative cooling walls constitute a passive cooling strategy to reduce temperature in urban surfaces that may involve sprinkling walls or roofs with water. This requires a water supply, a pump and energy to maintain the system operating for several hours. Recent investigations use walls made with innovative porous ceramics with high water soaking-up ability [45]. Some authors [46,47], however, mention that the humid output may raise some health related issues.

3.1.2.4. Heat absorbing phase change materials - PCMs. These materials use chemical bonds to store or release heat hence reducing energy consumption. Depending on the air temperature PCMs can change from solid to liquid or liquid to solid, absorbing or releasing heat during the process. Therefore, they can absorb heat inside buildings avoiding excessive heating and reducing cooling needs. Early investigations used immersion processes and macrocapsules to integrate PCMs. These approaches have different drawbacks and so PCMs had no big market impact. Recent advances in the technology of micro-encapsulation changed this situation [48]. PCM's can be organic, paraffin based or non-paraffin based (Table 4), they can also be inorganic like salt hydrate and metallics (Table 5) or even inorganic eutectics when PCḾs are composed by two or more components which freezes and melts in a congruent manner (Table 6). There are several ways of using PCMs in construction, including microcapsules, planar or cylindrical elements. PCM in the microcapsules is wrapped in a polymer coating which then is mixed to mortars used in walls and ceilings. A list of several commercial PCMs (Table 7) recommended for building purposes are presented by Tyagi and Buddhi [49]. Athienitis [50] mentioned that the use of walls with PCMs allows for a reduction of $4{ }^{\circ} \mathrm{C}$ in the daytime maximum room temperature. Within the frame of the project MECLIDE (Structural Solutions with Special Materials for

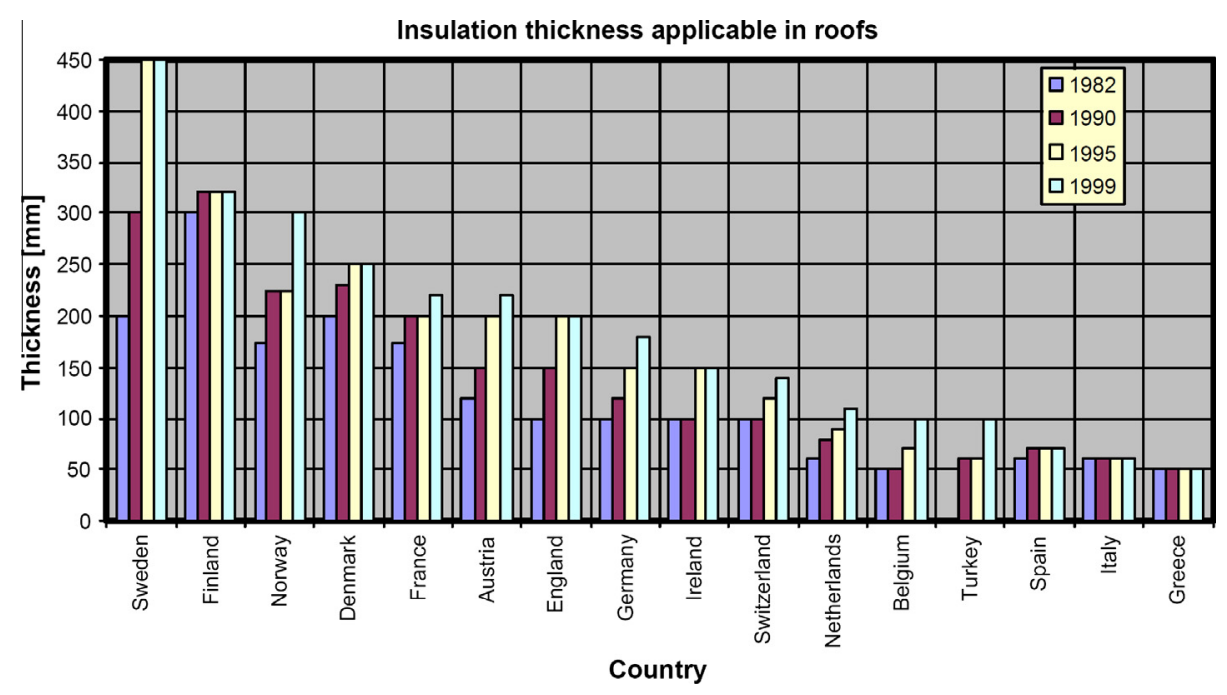

Fig. 4. Evolution of insulation thickness applicable in roofs in Europe [35]. 
Table 2

Description of the existing technological trends on the field of reflective pavements [43].

\begin{tabular}{|c|c|c|c|c|c|}
\hline No. & $\begin{array}{l}\text { Description of the } \\
\text { technology to increase } \\
\text { the Albedo }\end{array}$ & Technological details & $\begin{array}{l}\text { Type of } \\
\text { pavement }\end{array}$ & $\begin{array}{l}\text { Final albedo } \\
\text { achieved }\end{array}$ & Thermal benefits \\
\hline \multirow[t]{2}{*}{1.} & \multirow[t]{2}{*}{$\begin{array}{l}\text { Use of white high } \\
\text { reflective paints on the } \\
\text { surface of the pavement }\end{array}$} & $\begin{array}{l}\text { Use of } 14 \text { high reflectivity white paints placed } \\
\text { on the surface of concrete tiles }\end{array}$ & Concrete & $0.80-0.90$ & $\begin{array}{l}\text { Reduce of the daily surface temperature of a whitt } \\
\text { concrete pavement under hot summer conditions by } \\
4 \mathrm{~K} \text { and by } 2 \mathrm{~K} \text { during the night }\end{array}$ \\
\hline & & $\begin{array}{l}\text { High reflectivity white paints based on the use } \\
\text { of calcium hydroxide placed on the surface of } \\
\text { concrete tiles }\end{array}$ & Concrete & 0.76 & $\begin{array}{l}\text { Reduce of the daily surface temperature under hot } \\
\text { summer conditions by } 1-5 \mathrm{~K} \text { and by } 1 \mathrm{~K} \text { during the } \\
\text { night compared to a same color concrete pavemen }\end{array}$ \\
\hline \multirow[t]{4}{*}{2.} & \multirow[t]{4}{*}{$\begin{array}{l}\text { Use of Infrared reflective } \\
\text { colored paints on the } \\
\text { surface of the pavement }\end{array}$} & $\begin{array}{l}\text { Use of ten infrared reflective paints of different } \\
\text { color placed on the surface of concrete tiles }\end{array}$ & Concrete & $0.27-0.70$ & $\begin{array}{l}\text { Reduce of the daily surface temperature under hot } \\
\text { summer conditions by } 2-10 \mathrm{~K} \text { compared to a same } \\
\text { color concrete pavement }\end{array}$ \\
\hline & & $\begin{array}{l}\text { Use of a dark infrared reflective paint placed on } \\
\text { the surface of asphalt together with hollow } \\
\text { ceramic particles on the mass of the pavement }\end{array}$ & Asphalt & 0.46 & $\begin{array}{l}\text { Reduce of the daily surface temperature by } 5 \mathrm{~K} \\
\text { compared to a same color concrete }\end{array}$ \\
\hline & & $\begin{array}{l}\text { Use of a dark infrared reflective paint placed on } \\
\text { surface of asphalt together with hollow ceramic } \\
\text { particles }\end{array}$ & Asphalt & 0.50 & $\begin{array}{l}\text { Reduce of the daily surface temperature of the } \\
\text { pavement by } 8-15 \mathrm{~K} \text { and by } 2 \mathrm{~K} \text { during the night } \\
\text { compared to conventional asphalt }\end{array}$ \\
\hline & & $\begin{array}{l}\text { Five thin reflective layers of different colors } \\
\text { using infrared reflective pigments for asphaltic } \\
\text { pavements }\end{array}$ & Asphalt & $0.27-0.55$ & $\begin{array}{l}\text { Reduce of the daily surface temperature of the } \\
\text { pavement by } 16-24 \mathrm{~K} \text { and by } 2 \mathrm{~K} \text { during the night. } \\
\text { compared to conventional asphalt }\end{array}$ \\
\hline \multirow[t]{2}{*}{3.} & \multirow{2}{*}{$\begin{array}{l}\text { Use of heat reflecting } \\
\text { paint to cover } \\
\text { aggregates of the } \\
\text { asphalt }\end{array}$} & $\begin{array}{l}\text { Use of a reflecting paint to cover all aggregates } \\
\text { of the asphalt }\end{array}$ & Asphalt & $0.46-0.57$ & $\begin{array}{l}\text { Reduce of the daily surface temperature of the } \\
\text { pavement by } 10.2-18.8 \mathrm{~K} \text {, compared to conventional } \\
\text { asphalt }\end{array}$ \\
\hline & & $\begin{array}{l}\text { Use of a reflecting paint to cover the surface } \\
\text { aggregates of the asphalt }\end{array}$ & Asphalt & $0.25-0.6$ & $\begin{array}{l}\text { Reduce of the daily surface temperature of the } \\
\text { pavement by } 6.8-20 \mathrm{~K} \text {, compared to conventional } \\
\text { asphalt }\end{array}$ \\
\hline 4. & $\begin{array}{l}\text { Use of color changing } \\
\text { paints on the surface of } \\
\text { the pavement }\end{array}$ & $\begin{array}{l}\text { Use of eleven thermochromic colors applied on } \\
\text { the surface of concrete pavements }\end{array}$ & Concrete & $\begin{array}{l}\text { Colored: } \\
0.51-0.78 \\
\text { Colorless: } \\
0.71-0.81\end{array}$ & $\begin{array}{l}\text { Reduce of the daily surface temperature of the } \\
\text { pavement by } 5.4-10 \mathrm{~K} \text {, compared to conventional } \\
\text { pavements }\end{array}$ \\
\hline 5. & $\begin{array}{l}\text { Use of fly ash and slag as } \\
\text { constituents of the } \\
\text { concrete }\end{array}$ & $\begin{array}{l}\text { When } 70 \% \text { of slag is used as cement } \\
\text { replacement the mix presented an increased } \\
\text { albedo }\end{array}$ & Concrete & 0.58 & Not available \\
\hline
\end{tabular}

Table 3

Description of the existing technological trends on the field of permeable and water retentive pavements [43].

\begin{tabular}{|c|c|c|c|}
\hline No. & Description of the technology & $\begin{array}{l}\text { Type of } \\
\text { pavement }\end{array}$ & Thermal performance \\
\hline 1. & $\begin{array}{l}\text { Use of water holding fillers made of steel by products } \\
\text { as an additive to porous asphalt }\end{array}$ & Asphalt & $\begin{array}{l}\text { The average surface temperature of the water holding pavement was } 0.6 \mathrm{~K} \text { lower than } \\
\text { that of the infiltration porous asphalt bv }\end{array}$ \\
\hline 2. & $\begin{array}{l}\text { Use of fine blast-furnace powder in water retentive } \\
\text { asphalt }\end{array}$ & Asphalt & Its surface temperature was $14 \mathrm{~K}$ lower that of a dense graded asphalt pavement \\
\hline 3. & $\begin{array}{l}\text { Use of fine texture pervious mortar as an additive to } \\
\text { pervious concrete }\end{array}$ & Concrete & Data are not available \\
\hline 4. & $\begin{array}{l}\text { Use of bottom ash and peat moss as additives in } \\
\text { pervious concrete }\end{array}$ & Concrete & $\begin{array}{l}\text { It presents almost } 18 \mathrm{~K} \text { lower surface temperature than asphalt after a rainfall, while the } \\
\text { maximum surface temperature difference with the conventional porous pavement was } \\
\text { almost } 9 \mathrm{~K}\end{array}$ \\
\hline 5. & $\begin{array}{l}\text { Use of fly ash with very narrow particle size } \\
\text { distribution in bricks }\end{array}$ & Ceramic & Decrease of the surface temperature by several degrees. \\
\hline 6. & $\begin{array}{l}\text { Use of industrial wastes as raw material for ceramic } \\
\text { tiles }\end{array}$ & Ceramic & $\begin{array}{l}\text { Its surface temperature was almost } 10 \mathrm{~K} \text { lower than that of the dry material and almost } \\
25 \mathrm{~K} \text { cooler than the surface temperature of conventional asphalt }\end{array}$ \\
\hline
\end{tabular}

Deferred Air Conditioning of Buildings) some weaknesses of existing PCM solutions for buildings were identified as well as the innovative integration of PCM in the building structure [51]. RodriguezUrbinas et al. [52] used PCM drywall panels in the retrofitting of a building with low thermal mass showing that they are feasible for reducing thermal peaks. Another application for PCMs regarding the reduction of cooling needs relates to the free cooling of buildings. This is emerging passive way of building ventilation especially in the climatic conditions where the temperature difference between day and night in summer is at least $15^{\circ} \mathrm{C}$. However, this technology is still far from a mature state $[53,54]$.

3.1.2.5. Cool roofing materials. These materials are defined as having high solar reflectance and high infrared emittance. They can also be assessed by using the solar reflectance index (SRI). The
Table 4

Organic substances suitable for PCM's [49].

\begin{tabular}{lll}
\hline Compound & Melting point $\left({ }^{\circ} \mathrm{C}\right)$ & $\begin{array}{l}\text { Heat of fusion } \\
(\mathrm{kJ} / \mathrm{kg})\end{array}$ \\
\hline Butyl stearate & 19 & 140 \\
Paraffin $\mathrm{C}_{16}-\mathrm{C}_{18}$ & $20-22$ & 152 \\
Capric-lauric acid & 21 & 143 \\
Dimethyl sabacate & 21 & 120 \\
Polyglycol E600 & 22 & 127.2 \\
Paraffin $\mathrm{C}_{13}-\mathrm{C}_{24}$ & $22-24$ & 189 \\
$34 \%$ Mistiric acid $+66 \%$ capric acid & 24 & 147.7 \\
1-Dodecanol & 26 & 200 \\
Paraffin $\mathrm{C}_{18}(45-55 \%)$ & 28 & 244 \\
Vynil stearate & $27-29$ & 122 \\
Capric acid & 32 & 152.7 \\
\hline
\end{tabular}


Table 5

Inorganic substances suitable for PCM's [49].

\begin{tabular}{lll}
\hline Compound & Melting point $\left({ }^{\circ} \mathrm{C}\right)$ & Heat of fusion $(\mathrm{kJ} / \mathrm{kg})$ \\
\hline $\mathrm{KF} \cdot 4 \mathrm{H}_{2} \mathrm{O}$ & 18.5 & 231 \\
$\mathrm{Mn}\left(\mathrm{No}_{3}\right)_{2} \cdot 6 \mathrm{H}_{2} \mathrm{O}$ & 25.8 & 125.9 \\
$\mathrm{CaCl}_{2} \cdot 6 \mathrm{H}_{2} \mathrm{O}$ & 29 & 190.8 \\
$\mathrm{LiNO}_{3} \cdot 3 \mathrm{H}_{2} \mathrm{O}$ & 30 & 296 \\
$\mathrm{Na}_{2} \mathrm{SO}_{4} \cdot 10 \mathrm{H}_{2} \mathrm{O}$ & 32 & 251 \\
\hline
\end{tabular}

Table 6

Eutectics substances suitable for PCM's [49].

\begin{tabular}{lll}
\hline Compound & $\begin{array}{l}\text { Melting point } \\
\left({ }^{\circ} \mathrm{C}\right)\end{array}$ & $\begin{array}{l}\text { Heat of } \\
\text { fusion } \\
(\mathrm{kJ} / \mathrm{kg})\end{array}$ \\
\hline $66.6 \% \mathrm{CaCl}_{2} \cdot 6 \mathrm{H}_{2} \mathrm{O}+33.3 \% \mathrm{Mgcl}_{2} \cdot 6 \mathrm{H}_{2} \mathrm{O}$ & 25 & 127 \\
$48 \% \mathrm{CaCl}_{2}+4.3 \% \mathrm{NaCl}+0.4 \% \mathrm{KCl}+47.3 \%$ & 26.8 & 188 \\
$\mathrm{H}_{2} \mathrm{O}$ & & \\
$47 \% \mathrm{Ca}\left(\mathrm{NO}_{3}\right)_{2} \cdot 4 \mathrm{H}_{2} \mathrm{O}+53 \% \mathrm{Mg}\left(\mathrm{NO}_{3}\right)_{2} \cdot 6 \mathrm{H}_{2} \mathrm{O}$ & 30 & 136 \\
$60 \% \mathrm{Na}\left(\mathrm{CH}_{3} \mathrm{COO}\right) \cdot 3 \mathrm{H}_{2} \mathrm{O}+40 \% \mathrm{CO}\left(\mathrm{NH}_{2}\right)_{2}$ & 30 & 200.5 \\
\hline
\end{tabular}

Table 7

Commercial PCM's [49].

\begin{tabular}{llll}
\hline Designation & Substance & Melting point $\left({ }^{\circ} \mathrm{C}\right)$ & Heat of fusion $(\mathrm{kJ} / \mathrm{kg})$ \\
\hline RT20 & Paraffin & 22 & 172 \\
Climsel23 & Salt hydrate & 23 & 148 \\
Climsel24 & Salt hydrate & 24 & 216 \\
RT26 & Paraffin & 25 & 131 \\
RT25 & Paraffin & 26 & 232 \\
STL27 & Salt hydrate & 27 & 213 \\
S27 & Salt hydrate & 27 & 207 \\
RT30 & Paraffin & 28 & 206 \\
RT27 & Paraffin & 28 & 179 \\
TH29 & Salt hydrate & 29 & 188 \\
Climsel32 & Salt hydrate & 31 & 212 \\
RT32 & Paraffin & 32 & 130
\end{tabular}

SRI has a value of zero (for the standard black surface) and of 100 (for the standard white surface) [55]. The development of coatings with the objective of increasing solar reflectance of roofing materials is reported by Levison et al. [56]. Other authors [57] mentioned that the replacement of dark colored materials with materials of the same color containing near infrared reflecting pigments also reduces surface temperatures significantly. Synnefa et al. [58] describes the case of a school building in which the solar reflectance of the roof has changed from 0.2 to 0.89 after application of a white elastomeric cool coating. The thermal performance results shows that the annual cooling energy load was reduced by $40 \%$ (although a $10 \%$ heating penalty also has taken place). This is one of the most common drawbacks for high reflectance cool roofing materials. That is why the development of dynamic optical characteristics are an important research line [55].

3.1.2.6. Green façades and green roofs. Last but not the least, concerns the case of green façades and roofs. Although not being an innovative technique (first attempts to quantify energy benefits occurred in the $60 \mathrm{~s}$ [59]) the greening of the building envelope by using vegetation is a growing trend and some countries show a remarkable acceptation of such "technology". For instance, Germany has almost 100 million $\mathrm{m}^{2}$ of green roofs, and the state of Singapore intends to target 0.75 ha of green roofs per 1000 inhabitants. Green façades can include all vertical greening systems however some authors [60] use the term "green façades" only when climbers attached directly to the building surface are used while prefabricated and prevegetated systems (living wall systems), attached to walls are termed as "living wall systems". Green roofs come in two forms, extensive and intensive. The former has between 50 and $150 \mathrm{~mm}$ of growing medium to support plant life. This fact limits the size of plants that can be used on the roof, thus limiting the weight of the green roof on the building structure. Generally foot traffic is not allowed on extensive green roofs. On the other hand, intensive green roofs generally need from 150 to $1200 \mathrm{~mm}$ of growing medium to allow for larger vegetated species and even trees [61]. Fig. 5 shows the typical cross-section through a green roof. Extensive green roofs not only are relatively maintenance free and capable of surviving in European climates but they are also the preferred option for retrofitting onto existing buildings as the structural capacity of the roof will often not have to be increased. Besides they are especially beneficial for buildings with poor insulated roofs $[62,63]$. Both green roofs $[64,65]$ and green façades $[66,67]$ can contribute to the reduction of building cooling needs. However, a higher cooling effectiveness takes place with green roofs. Some studies [68] show that green roofs performance depend on the water content for a good cooling performance (by evapotranspiration) being that water from rainfall is not enough (at least in the South of Europe). Ascione et al. [59] have analyzed the economical performances of five green roofs for different European climates, stating that green roofs are not advantageous for well-insulated buildings located in warm climates. These authors also mention that the amount of required irrigation is a key node in order to achieve benefits. The use of an artificial water irrigation system may override the financial benefits of green roofs. However, it is important to highlight that this analysis forgets the economical advantages related to the mitigation of urban heat island effects or even the reduction of urban pollution. Green building envelope is particularly important because recent investigations show that there is a strong correlation between the lack of green infrastructures in the urban environment and the increase of allergy related health problems [69]. Besides green façades and green roofs merit a special attention of the EU policy. In May 6 of 2013 the EU adopted a new strategy for encouraging the use of green infrastructure [70]. By the end of 2013, the Commission will develop guidance to show how green infrastructure can be integrated into the implementation of these policies from 2014 to 2020, for several areas, including adaptation to climate change.

\subsubsection{The importance of materials with lower embodied energy}

There is a limit beyond which no further reductions on energy consumption can be achieved within the EPBD framework. Therefore, the use of building materials with lower embodied energy becomes a priority area. The energy embodied in construction and building materials (embodied energy) covers the energy consumed during its service life. There are, however, different approaches to this definition, namely: including the energy consumed from the extraction of raw materials to the factory gate (cradle to gate), from extraction to site works (cradle to site) or from extraction

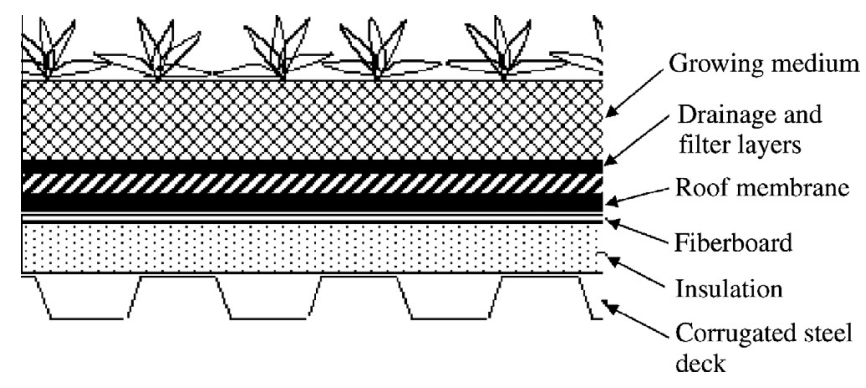

Fig. 5. Typical cross-section through a green roof [61]. 
to the demolition and disposal (cradle to grave). Berge [71] considers as embodied energy only the energy needed to bring the material or product to the factory gate (first case), and the transport energy and the energy related to the work execution as being both included in the construction phase of the building. According to this author, the embodied energy represents $85-95 \%$ of the material total energy (the remaining $5-15 \%$ being related to the construction, maintenance and demolition of the building). As to the third case, the embodied energy includes all energy consumption phases from the production at the cradle. As to the transport energy, it depends on the mode of transport: sea, air, road or rail. In recent decades the operational energy in buildings (lighting, heating, cooling, etc.) was accepted as being the major contributor, while the embodied energy was found to represent only a small fraction (10-15\%). Consequently much effort has been made towards the reduction of operational energy by increasing the energy efficiency of buildings. However, as operational energy is reduced, the percentage of the embodied energy in the total energy consumption of the buildings becomes increasingly prevalent. Thormark [72] studied one of the lowest energy consumption buildings in Sweden $\left(45 \mathrm{~kW} \mathrm{~h} / \mathrm{m}^{2}\right)$ referring that the embodied energy for a lifetime of 50 years could represent almost $45 \%$ of the total energy. Some authors [73], recognized that energy savings by means of more efficient thermal insulation (as well as increasing renewable energy use) is an insufficient approach further suggesting the inclusion of embodied energy as an important parameter for sustainable construction. Szalay [74] even suggested that the EPBD Recast could include requirements on embodied energy. Unfortunately that was not the case. Instead the European strategy decided to addresses the overall environmental impact of construction and building materials (energy consumption included) in the new Construction Products Regulation-CPR [75] which is in effect since 1 July of 2013. Recently Pacheco-Torgal et al. [76] studied a 97 apartment-type building $\left(27,647 \mathrm{~m}^{2}\right)$ located in Portugal, concerning both embodied energy as well as operational energy. The results show that the embodied energy in reinforced concrete (concrete plus steel) represents $70 \%$ of the total; therefore, high energy reductions can only occur by lowering the energy in this material. The operational energy was found to signify an average of $187.2 \mathrm{MJ} / \mathrm{m}^{2} / \mathrm{yr}$ and the embodied energy accounting for approx. $2372 \mathrm{MJ} / \mathrm{m}^{2}$ and representing just $25.3 \%$ of the former. If the buildings were in the AA + energy class, this would mean that the embodied energy could be almost 4 times the operational energy for a service life of 50 years. A recent review by Cabeza et al. [77] highlights the research efforts to develop new materials with less embodied energy.

\subsection{Materials capable of reusing a high waste content}

The need to recycle at least $70 \%$ of non-hazardous construction and demolition waste by 2020 expressed in COM 571 [8] was set by the Revised Waste Framework Directive 2008/98/EC [78] and does not include naturally occurring material defined in category 170504 (soil and stones not containing dangerous substances) in the European Waste Catalogue". Eurostat estimates the total for Europe to be 970 million tons/year, representing an average value of almost 2.0 ton/per capita [79]. As the current average recycling rate of CDW for EU-27 is only $47 \%$ increasing it by $70 \%$ in just a decade seems an ambitious goal, further stressing the need for effective recycling methods [80]. Also important is the need for new and updated standards. For instance the existent standards on the use of recycled aggregates on high strength concrete limit its content to no more than $30 \%$ in volume, although investigation results on this field already allow for much higher replacing rates [81]. Standardization is, therefore a crucial step concerning the development of materials for increasing waste content recycling [82]. The milestone related to the recycling of other kinds of waste can be found in the Roadmap to a Resource Efficient Europe [8]:

By 2020, waste is managed as a resource. Waste generated per capita is in absolute decline. Recycling and re-use of waste are economically attractive options for public and private actors due to widespread separate collection and the development of functional markets for secondary raw materials. More materials, including materials having a significant impact on the environment and critical raw materials, are recycled. Waste legislation is fully implemented. Illegal shipments of waste have been eradicated. Energy recovery is limited to non recyclable materials, landfilling is virtually eliminated and high quality recycling is ensured.

Mining and quarrying wastes represent another worrying waste (more than 700 million tons/year) that can be reused in construction materials. Mineral waste can be defined as the 'residues, tailings or other non-valuable material produced after the extraction and processing of material to form mineral products' [83]. Not very long ago the failure cases of Aznalcollar mine in Spain (1998) which affected 2656 ha of Donana Nature Park with pyrite sludge and Baia Mare mine (2000) in Romania clearly showed that in a short term and environmentally speaking mine wastes represent a clear and present danger as important as climate change [84]. Although some investigations [85-87] revealed a high potential of waste reuse new research efforts on innovative construction materials capable of immobilizing wastes with toxic substances are needed. The information regarding hazardous substances is a crucial aspect in the new Construction Products Regulation. CPR links this subject to the (EC) No 1907/2006 (Registration, Evaluation, Authorization and Restriction of Chemicals - REACH Regulation) [26]. Meanwhile, a recent COST action termed NORM4 Building materials was approved in 15 May 2013. NORM4 Building materials intends to stimulate research on the reuse of industrial residues containing toxic agents. In the next years waste recycling will be more and more challenging on the zero waste visionary scenario $[88,89]$. Further investigation is needed on the field of waste recycling LCA [90,91]. Nevertheless, the feasibility of waste reusing depends on the high demand of bulk materials like Portland cement concrete and, since the European consumption of this material has stagnated (Fig. 6), this does not seem to be a very hot area. Besides, reusing wastes is not on the core of the Horizon 2020 like, for instance, KETs are. According to the COM 808 [2] KET's are a key priority of Horizon 2020 in terms of their contribution for growth and job creation.

\section{A KET related to nanotech energy efficiency building materials}

KETs are knowledge and capital-intensive technologies associated with high research and development $(R \& D)$ intensity, rapid and integrated innovation cycles, high capital expenditure and highly-skilled employment. Their influence is pervasive, enabling process, product and service innovation throughout the economy. They are of systemic relevance, multidisciplinary and trans-sectorial, cutting across many technology areas with a trend towards convergence, technology integration and the potential to induce structural change" [93]. Horizon 2020 [2] mentions six KETs that were choosen in 2009 by the European Commission: nanotechnology, micro-nanoelectronics, advanced materials, photonics, industrial biotechnology and advanced manufacturing systems. The gap between basic knowledge generation and the subsequent commercialization of this knowledge in marketable products, has been commonly identified across the KETs and is known in broad terms 


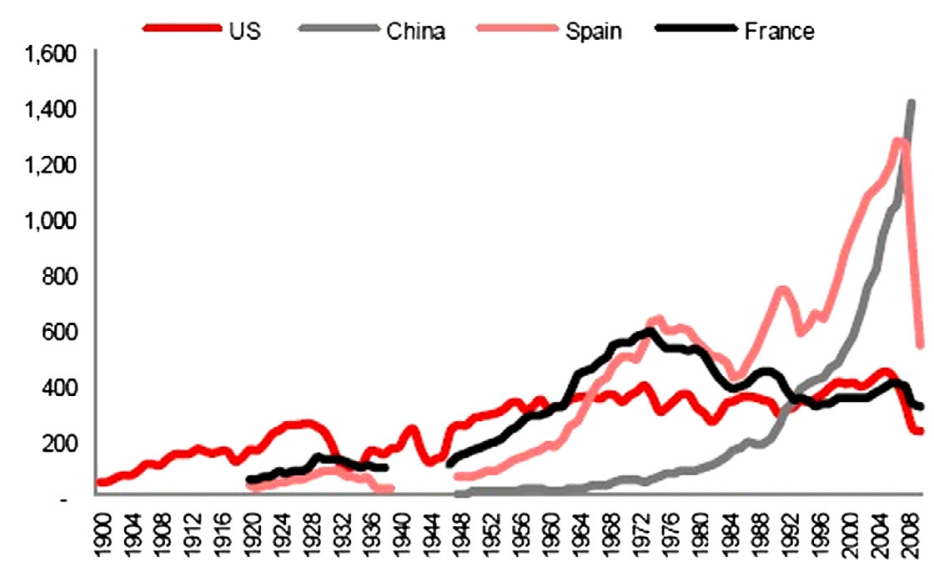

Source: SG Cross Asset Research, US Geological Survey, Italcementi

Fig. 6. Cement consumption per capita (kg) [92].

as the "valley of death" issue. The crossing of the "valley of death" in the KETs can therefore be imagined as constructing a European bridge comprising three following pillars (Fig. 7):

- The technological research pillar based on technological facilities supported by research technology organization.

- The product development pillar based on pilot lines and demonstrator supported by industria consortia.

- The competitive manufacturing pillar based on globally competitive manufacturing facilities supported by anchor companies [93].

Nanotech energy efficiency building materials seem to fit on the KETs definition because they constitute a key area for growth and job creation. Weinberger et al. [94] compared several environmental technologies mentioning that the highest market potentials were measured for technologies in building energy efficiency. Besides a recent report [95] shows that the global market for energy efficient building will go from 68 billion dollars in 2011 surpassing 100 billion dollars by 2017 :
Aerogel is a perfect example of a high performance thermal insulation material and according to Jelle "may be the most promising with the highest potential of them all at the moment" [96].

Aerogel was was invented by Samual Kistler in 1932 [97] and further developed by NASA in the 1950s and has been known as "solid smoke" (the lowest density solid known). It is composed of air above $90 \%$ and silica nanoparticles having the lowest thermal conductivity of any solid (around $0.01 \mathrm{~W} / \mathrm{mK}$ ). Aerogel insulation is non-flammable, not carcinogenic [98] and does not release toxic fumes during fire however, current cost of this product is in the range of $25 € / \mathrm{m}^{2}$ which is almost 10 times higher when compared to conventional insulation material for the same thermal resistance [99]. Since the majority of energy losses in a building occur through windows the improvements of windows thermal performance is crucial for building energy efficiency. Traditional double glazed windows show a thermal transmittance around $U=3 \mathrm{~W} /$ $\mathrm{m}^{2} \mathrm{~K}$ and the best commercial solution can go down to $U=1 \mathrm{~W} /$ $\mathrm{m}^{2} \mathrm{~K}$. Aeerogel based windows constitute very promising high tech alternatives. Not only do they have a much lower mass (as much as 10 times lower [100]) but they also show a thermal transmittance

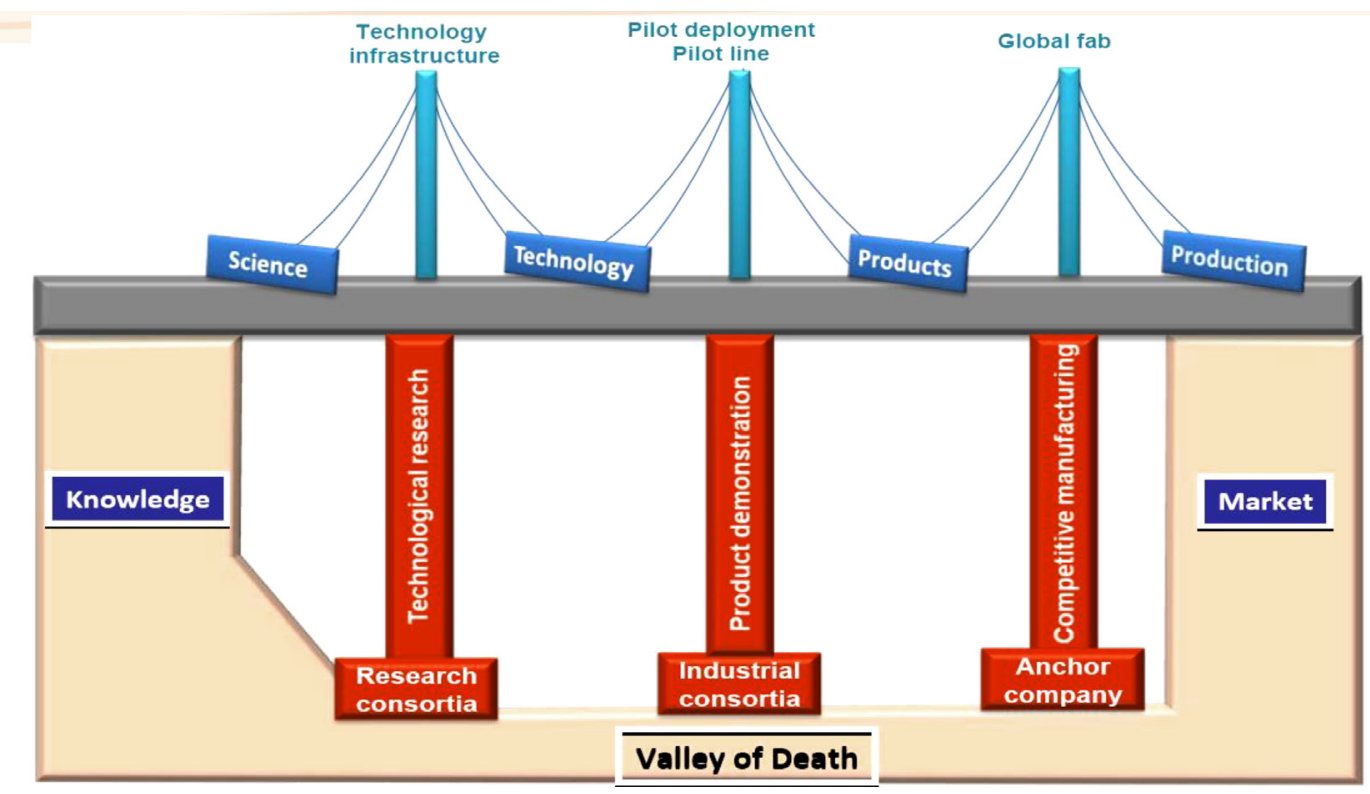

Fig. 7. The 3 Pillar Bridge to cross the valley of death [93]. 

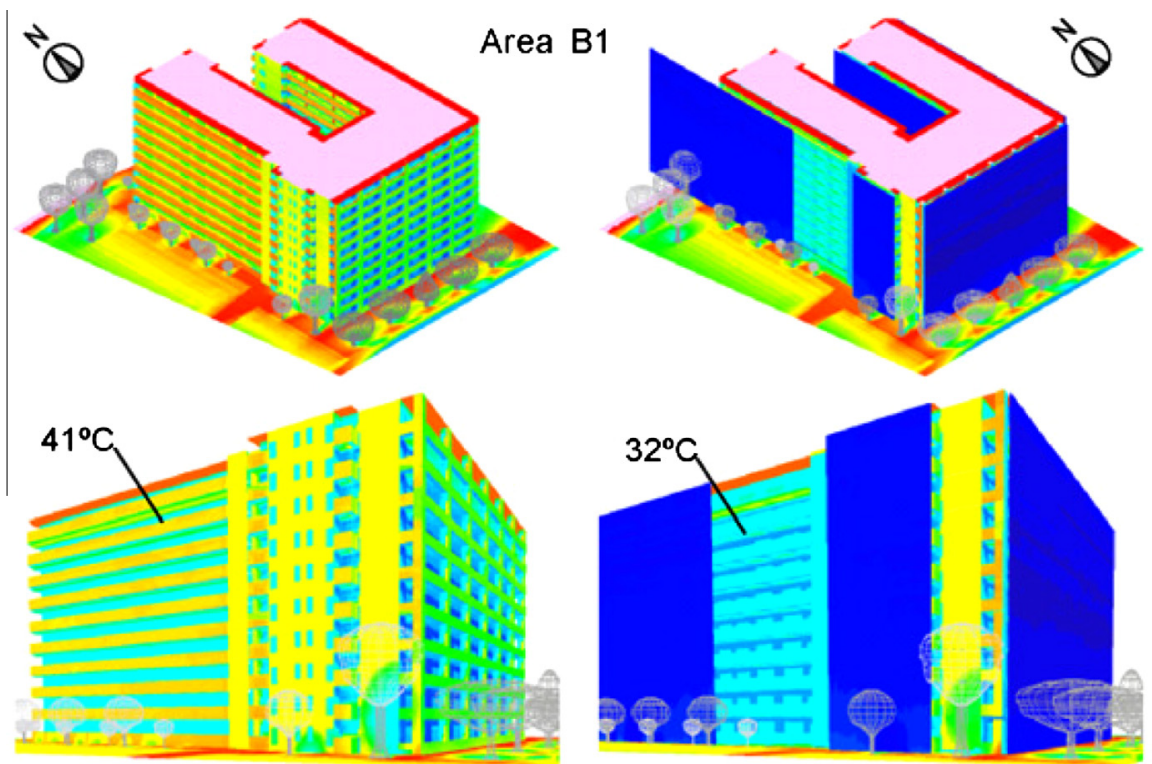

Without watering
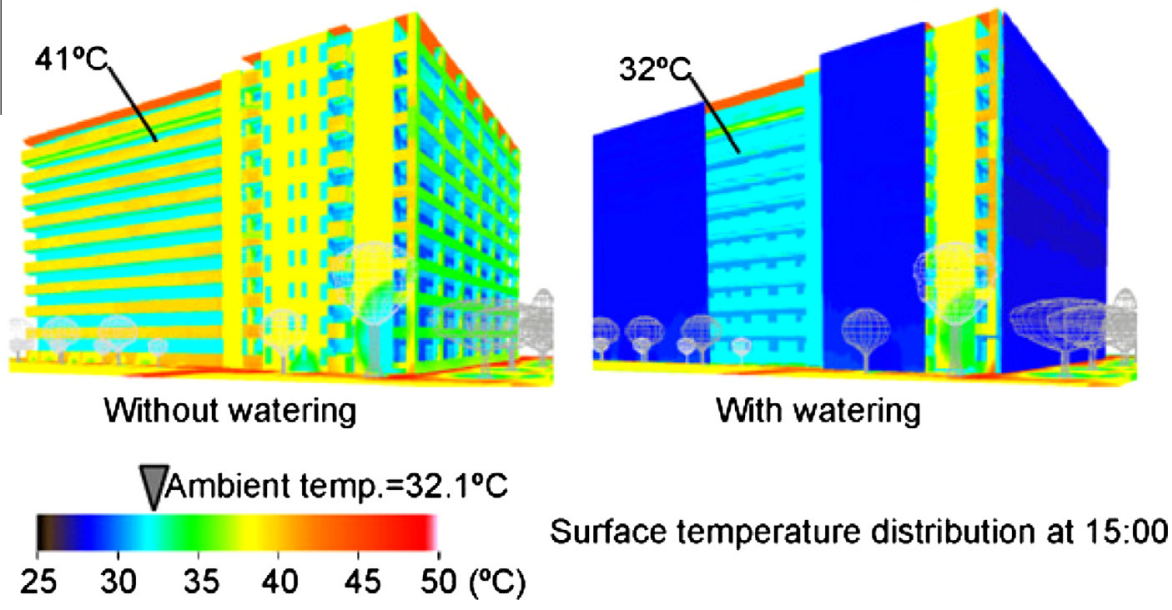

Fig. 8. Simulated results of surface temperature on a sunny day (August 5) in the summer of Tokyo [103].

of around $0.5 \mathrm{~W} / \mathrm{m}^{2} \mathrm{~K}$. This value can additionally be reduced even further [101]. The eco-efficiency of aerogel windows still remains to be proven by life cycle assessment investigations. Investigations on the field of photo induced super-hydrophilicity show that for walls with $\mathrm{TiO}_{2}$ coating water can form a very thin film (only $0.1 \mathrm{~mm}$ ) thus meaning that just $200 \mathrm{ml} / \mathrm{min}$ can cover a $5 \mathrm{~m}^{2}$ wall [102]. Some authors [103], developed a numerical model to simulate the thermal improvement of sprinkling water on the $\mathrm{TiO}_{2}$ coated external building surfaces (Fig. 8) showing that the indoor air temperature decreased by $2-4{ }^{\circ} \mathrm{C}$ and the daily building-cooling load was reduced by $30-40 \%$, as compared to a building without water flow. Another high priority research line concerns the envelopment of colored and white cool materials incorporating the new advanced nano-materials [55]. The development of nano-encapsulated phase change materials for façades components is also important [104] this research line was mentioned by the High level group on KETs on the nanotechnology report [105]. Also crucial is switchable glazing technology based materials. This refers to 'materials and devices that make it possible to construct glazings whose throughput of visible light and solar energy can be switched to different levels depending on the application of a low DC voltage (electrochromics) or on the temperature (thermochromics) or even by using hydrogen (gasochromics). Electrochromic windows have shown a 54\% energy reduction in electrochromic windows when compared to standard single glazed windows for a 25 years life cycle [106]. Other authors [107] studied gasochromics windows reporting a $34 \%$ reduction on cooling needs when compared to standard double glazed windows. Several commercial solutions are already available on the market (SAGE Electrochromics-USA, Econtrol Glas, Saint Gobain Sekurit and Gesimat-Germany, ChromoGenics AB-Sweden, amongst others) with a service life of 30 years and capable of 100,000 switching cycles. However, it is expected that in the next years, a higher performance and lower cost switchable glazing windows will be available [108]. Some authors $[109,110]$ consider switchable windows a promising technology on the recent concept of climate adaptive building shells capable of operating in harmony with Nature. It is important to stress that market for this products is predicted to increase from current $\$ 84$ million to $\$ 700$ million by 2020 [111].

\section{Conclusions}

The program Horizon 2020 is part of the Europe 2020 strategy to promote smart, sustainable and inclusive growth having a overall budget of around 70,000 million $€$ for the next 7 years (20142020). Horizon 2020 will consist of three main pillars. The first is excellent science, the second is industrial leadership and the third concerns societal challenges. Horizon 2020 dedicates a special attention to sustainable development, through climate action and resource efficiency that will represent at least $60 \%$ of the overall budget. This could have a strong impact on the future of the European construction industry. Climate action will determine the future actions on the construction sector because current and future infrastructure will need to be adapted to natural disasters including climate change events like floods, windstorms, droughts, fires, heat and cold waves, sea level rise and even landslides. It is noteworthy that the European construction industry can benefit from Horizon opportunities in order to become world competitive in the climate-resilient area. Under the sustainable development focus of Horizon 2020 some construction and building materials research lines will deserve a special attention. This include ecoefficient thermal insulators, materials for mitigating building cooling needs, materials with reduced embodied energy, materials capable of reusing a high waste content and nanotech energy efficiency building materials. Development of construction materials capable of reusing a high waste content is an important research line in order to fulfill the resource efficient Europe 2020 milestone related to the management of waste as a resource. Nevertheless, the feasibility of waste reusing depends on the demand of bulk 
materials like Portland cement concrete and, since its European consumption has stagnated, this does not seem to be a very hot area. Green building envelope is particularly important because recent investigations show that there is a strong correlation between the lack of green infrastructures in the urban environment and the increase of allergy related health problems. Besides green façades and green roofs merit a special attention of the EU policy. Nanotech energy efficiency building materials seem to fit on the KETs definition because they constitutes a key area for growth and job creation. It also has the potential to become a hot research area being promoted under the Key Enabling Technology-KET. Switchable nanotech materials merit a special interest because they relate to a recent concept of climate adaptive building shells capable of operating in harmony with Nature.

\section{References}

[1] COM 2020. A strategy for smart, sustainable and inclusive growth. 2010.

[2] COM 808. EU Framework programme for research and Innovation-Horizon 2020. 2011.

[3] Rabesandratana T, Vogel G. At long last, Europe’s mega R\&D program comes into focus. Sci Mag 2013;21.

[4] Delanghe H, Sloan B, Muldur G. European research policy and bibliometric indicators, 1990-2005. Scientometrics 2010;87:389-98.

[5] Ruiz-Castillo J, Herranz N. The end of the "European Paradox". Scientometrics 2013;95:453-64.

[6] FIEC. Construction in Europe: key figures. Activity 2010. Brussels, 2013.

[7] Goulding J, Nadim W, Petridis P, Alshawi M. Construction industry offsite production: a virtual reality interactive training environment prototype. Adv Eng Inform 2012;26:103-16.

[8] COM 571. Roadmap to a resource efficient Europe. 2011.

[9] E.E.A. Report 12. Climate change, impacts and vulnerability in Europe 2012. Copenhagen: European Environment Agency; 2012.

[10] COM 216. An EU strategy on adaptation to climate change. Brussels. 2013.

[11] SWD 137. Adapting infrastructure to climate change. Brussels. 2013.

[12] Giordano T. Adaptive planning for climate resilient long-lived infrastructures. Utilities Policy 2012;23(2012):80-9.

[13] Lomborg B. Solutions for the world biggest problems. Costs and benefits. Cambridge University Press; 2007.

[14] OECD. Green growth in cities. OECD Publishing; 2013.

[15] Kennedy C, Corfee-Morlot J. Past performance and future needs for low carbon climate resilient infrastructure - an investment perspective. Energy Policy 2013;59:773-83.

[16] UK. Climate resilient infrastructure: preparing for a changing climate. 2011.

[17] Edwards DJ, Dainty ARJ, Love PED. A sustainable cohort of professional civil engineering graduates? Uncovering the United Kingdom graduate crisis. Int Edu J 2004;5(3):374-84.

[18] Clarke B. Graduate civil engineers: defining a new breed. Proc Inst Civ Eng: Civ Eng 2005;158(2):89-98.

[19] Adeli H. Vision for civil and environmental engineering departments in the 21st century. J Professional Issues Eng Edu Pract 2009;135(1):1-3.

[20] Lechtenbohmer S, Schuring A. The potential for large-scale savings from insulating residential buildings in the EU. Energy Efficiency 2011;4:257-70.

[21] COM 885/2. Energy Roadmap 2050, Bussels. 2011.

[22] COM 815. Progress report on the Europe 2020 strategy. 2011.

[23] COM 639. Energy 2020 A strategy for competitive, sustainable and secure energy. Brussels. 2010.

[24] European Union. Directive 2010/31/EU of the European Parliament and of the Council of May 19th, 2010 on the energy performance of buildings (recast). Official Journal of the European Union; 18 June, 2010.

[25] Pacheco-Torgal F, Cabeza L, Mistretta M, Kaklauskas A, Granqvist CG. Nearly zero energy building refurbishment. London, UK: A multidisciplinary approach Springer Verlag; 2013.

[26] Pacheco-Torgal F, Fucic A, Jalali S. Toxicity of building materials. Cambridge, UK: Woodhead Publishing Limited Abington Hall; 2012.

[27] Liang $\mathrm{H}$, Ho M. Toxicity characteristics of commercially manufactured insulation materials for building applications in Taiwan. Constr Build Mater 2007;21:1254-61.

[28] Collet F. Caracterisation hydrique et thermique des materiaux á faibles impacts environnementaux. Ph.D. Thesis, INSA, Rennes. 2004.

[29] Kymalainen H, Sjoberg A. Flax and hemp fibers as raw materials for thermal insulations. Build Environ 2008;43:1261-9.

[30] Chikhi M, Agoudjil B, Boudenne A, Gherabli A. Experimental investigation of new biocomposite with low cost for thermal insulation. Energy and Buildings 2013;66:267-73.

[31] Zhou XY, Li HG, Lu CL. An environment-friendly thermal insulation material from cotton stalk fibers. Energy Build 2010;42:1070-4.

[32] Korjenic A, Zach J, Hroudova J. Development and performance evaluation of natural thermal-insulation materials composed of renewable resources. Energy Build 2011;43:2518-23.
[33] Green cork-based innovative resilient and insulating materials: Acoustic, thermal, and mechanical characterization. In: Proceedings of the ICA 2013, 1 16, Montreal, Canada.

[34] Zampori L, Dotelli G, Vernelli V. Life cycle assessment of hemp cultivation and use of hemp-based thermal insulator materials in buildings. Environ Sci Technol 2013;47(13):7413-20.

[35] Papadopoulos A. State of the art in thermal insulation materials and aims for future developments. Energy Build 2005;37:77-86.

[36] Simmler H, Brunner S. Vacuum insulation panels for building application. Basic properties, aging mechanisms and service life. Energy Build 2005;37:1122-31.

[37] Fricke J, Heinemann U, Ebert H-P. Vacuum insulation panels - from research to market. Vacuum 2008;7(82):680-90.

[38] Baetens R, Jelle B, Thue J, Tenpierik M, Grynning S, Uvslokk S, et al. Vacuum insulation panels for building applications: a review and beyond. Energy Build 2010;42:147-72.

[39] Balaras C, Grossman G, Henning H, Infante-Ferreira C, Podesser E, Wang L, et al. Solar air conditioning in Europe-an overview. Renew Sustain Energy Rev 2007:11:299-314.

[40] Crawley DB. Estimating the impacts of climate change and urbanization on building performance. J Build Perform Simulation 2008;1:91-115.

[41] Roetzel A, Tsangrassoulis A. Impact of climate change on comfort and energy performance in offices. Build Environ 2012;57:349-61.

[42] Allegrini J, Dorer V, Carmeliet J. Influence of the urban microclimate in street canyons on the energy demand for space cooling and heating of buildings. Energy Build 2012;55:823-32.

[43] Santamouris M. Using cool pavements as a mitigation strategy to fight urban heat island-a review of the actual developments. Renew Sustain Energy Rev 2013;26:224-40.

[44] Li H, Harvey J, Holland T, Kayhanian M. The use of reflective and permeable pavements as a potential practice for heat island mitigation and storm water management. Environ Res Lett 2013;8:015023.

[45] He J. Hoyano A. Experimental study of cooling effects of a passive evaporative cooling wall constructed of porous ceramics with high water soaking-up ability. Build Environ 2010;45:461-72.

[46] Samuel D, Nagendra S, Maiya M. Passive alternatives to mechanical air conditioning of building: a review. Build Environ 2013;66:54-64.

[47] Aldous M, Holberg C, Wright A, Martinez F, Taussig L, Bean J, et al. Evaporative cooling and other home factors and lower respiratory tract illness during the first year of life. Am J Epidemiol 1996;143:423-30.

[48] Schossig P, Hening H, Gschwander S, Haussmann T. Micro-encapsulated phase-change materials integrated into construction materials. Sol Energy Mater Sol Cells 2005;89:297-306.

[49] Tyagi V, Buddhi D. PCM thermal storage in buildings: a state of art. Renew Sustain Energy Rev 2007;11:1146-66.

[50] Athienitis A, Liu C, Hawe D, Hanu D, Feldman D. Investigation of the thermal performance of a passive-solar test-room with wall latent-heat storage. Build Environ 1997;32:405-10.

[51] Alvarez S, Cabeza L, Ruiz-Pardo A, Castelli A, Tenorio J. Building integration of PCM for natural cooling of buildings. Appl Energy 2013;109:514-22.

[52] Rodriguez-Ubinas E, Arranz BA, Sánchez SV, González FJN. Influence of the use of PCM drywall and the fenestration in building retrofitting. Energy Build 2013;65:464-76.

[53] Zalba B, Marin J, Cabeza L, Mehling H. Free cooling of buildings with phase change materials. Int J Refrigeration 2004;27:839-49.

[54] Waqas A, Din Z. Phase change material ( $\mathrm{pcm}$ ) storage for free cooling of buildings-a review. Renew Sustain Energy Rev 2013;18:607-25.

[55] Santamouris M, Synnefa A, Karlessi T. Using advanced cool materials in the urban built environment to mitigate heat islands and improve thermal comfort conditions. Sol Energy 2011;85:3085-102.

[56] Levinson R, Akbari H, Berdahl P, Wood B, Skilton W, Petersheim J. A novel technique for the production of cool colored concrete tile and asphalt shingle roofing products. Sol Energy Mater Sol Cells 2010;94(6):946-54.

[57] Synnefa A, Santamouris V, Apostolakis K. On the development, optical properties and thermal performance of cool colored coatings for the urban environment. Sol Energy J 2007;81(4):488-97.

[58] Synnefa A, Saliari M, Santamouris M. Experimental and numerical assessment of the impact of increased roof reflectance on a school building in Athens. Energy Build 2012;55:7-15.

[59] Ascione F, Bianco N, de Rossi F, Turni G, Vanoli G. Green roofs in European climates. Are effective solutions for the energy savings in air-conditioning? Appl Energy 2013;104:845-59.

[60] Ottelé M, Perini K, Fraaij ALA, Haas EM, Raiteri R. Comparative life cycle analysis for green façades and living wall systems. Energy Build 2011;43:3419-29.

[61] Kosareo L, Ries R. Comparative environmental life cycle assessment of green roofs. Build Environ 2007;42:2606-13.

[62] Castleton HF, Stovin V, Beck SBM, Davison JB. Green roofs; building energy savings and the potential for retrofit. Energy Build 2010;42:1582-91.

[63] Sadineni S, Madala S, Boehm R. Passive building energy savings: a review of building envelope components. Renew Sustain Energy Rev 2011;15: 3617-31.

[64] Niachou A, Papakonstantinou K, Santamouris M, Tsangrassoulis A, Mihalakakou G. Analysis of the green roof thermal properties and investigation of its energy performance. Energy Build 2001;33(7):719-29. 
[65] Kumar R, Kaushik SC. Performance evaluation of green roof and shading for thermal protection of buildings. Build Environ 2005;40(11):1505-11.

[66] Eumorfopoulou EA, Kontoleon KJ. Experimental approach to the contribution of plant covered walls to the thermal behaviour of building envelopes. Build Environ 2009;44:1024-38.

[67] Koyama T, Yoshinaga M, Hayashi H, Maeda K-I, Yamauchi A. Identification of key plant traits contributing to the cooling effects of green façades using freestanding walls. Build Environ 2013;66:96-103.

[68] Zinzi M, Agnoli S. Cool and green roofs. An energy and comfort comparison between passive cooling and mitigation urban heat island techniques for residential buildings in the Mediterranean region. Energy Build 2013:55(2012):66-76.

[69] Hanski I, Von Hertzen L, Fyhrquist N, Koskinen K, Torppa K, Laatikainen T, Karisola P, Auvinen P, Paulin L, Mäkelä M, Vartiainen E, Kosunen T, Alenius H, Haahtela T. Environmental biodiversity, human microbiota, and allergy are interrelated. In: Proceeding of the National Academy of Sciences of the United States of America. 2012. <http://www.pnas.org/content/early/2012/05/01/ 1205624109.full.pdf>.

[70] IP 404. Environment: Investing in green infrastructure will bring multiple returns to nature, society and people. 2013.

[71] Berge B. The ecology of building materials. 2 ed. Architectural Press, Elsevier Science; 2009. ISBN 978-1-85617-537-1.

[72] Thormark C. A low energy building in a life cycle - its embodied energy, energy need for operation and recycling potential. Build Environ 2002;37:429-35.

[73] Sandrolini F, Franzoni E. Embodied energy of building materials: a new parameter for sustainable architectural design. Int $J$ Heat Technol 2010;27:163-7.

[74] Szalay A. What is missing from the concept of the new European building directive? Build Environ 2007;42:1761-9.

[75] Directive (EU) 305/2011 - Construction products regulation. Official Journal of the European Union, European Parliament, Brussels.

[76] Pacheco-Torgal F, Faria J, Jalali S. Embodied energy versus operational energy. Showing the shortcomings of the energy performance building directive (EPBD). Mater Sci Forum 2013;730-732:587-91.

[77] Cabeza LF, Barreneche C, Miró L, Morera J, Bartolí E, Fernández A. Low carbon and low embodied energy materials in buildings: a review. Renew Sustain Energy Rev 2013;23:536-42.

[78] Directive 2008/98/EC - Revised Waste Framework. Official Journal of the European Union, European Parliament, Brussels.

[79] Sonigo P, Hestin M, Mimid S. Management of construction and demolition waste in Europe. Brussels: Stakeholders Workshop; 2010.

[80] Pacheco-Torgal F, Labrincha JA, Jalali S, John VM. Eco-efficient concrete. Cambridge, UK: Woodhead Publishing Limited Abington Hall; 2013. p. 592.

[81] Pacheco-Torgal F, Labrincha J, De Brito J, Tam V, Ding Y. Handbook of recycled concrete \& other demolition wastes. Cambridge, UK: Woodhead Publishing Limited Abington Hall; 2013.

[82] Sanjuan M, Zaragoza A, Agui J. Standardization for an innovative world. Cem Concr Res 2011;41:767-74.

[83] Harrison DJ, Bloodworth AJ, Eyre JM, Macfarlane M, Mitchell CJ, Scott PW, Steadman EJ. Utilisation of mineral waste:cases studies. BGS Commissioned, Report CR/02/227 N. 2002.

[84] Pacheco-Torgal F, Labrincha J. The future of construction materials research and the seventh UN Millennium development goal: a few insights. Constr Build Mater 2013;40:729-37.

[85] Pacheco-Torgal F, Castro-Gomes JP, Jalali S. Investigations of tungsten mine waste geopolymeric binders. Strength and microstructure. Constr Build Mater 2008;22:2212-9.

[86] Pacheco-Torgal F, Castro-Gomes JP, Jalali S. Tungsten mine waste geopolymeric binders. Preliminary hydration products. Constr Build Mater 2009;23:200-9.

[87] Pacheco-Torgal F, Castro-Gomes JP, Jalali S. Durability and environmental performance of alkali-activated tungsten mine waste mud mortars. J Mater Civ Eng-ASCE 2010;22:897-904.

[88] Phillips P, Tudor T, Bird H, Bates M. A critical review of a key waste strategy initiative in England: zero waste places projects 2008-2009. Resour Conserv Recycl 2011;55:335-43.
[89] Zaman AU, Lehmann S. The zero waste index: a performance measurement tool for waste management systems in a 'zero waste city'. I Clean Prod 2013;50(2013):123-32.

[90] Chen C, Habert G, Bouzidi Y, Jullien A, Ventura A. LCA allocation procedure used as an incitative method for waste recycling: an application to mineral additions in concrete. Resour Conserv Recycl 2010;54(12):1231-40.

[91] Pacheco-Torgal F, Labrincha J, Cabeza L, de Magalhães A. Eco-efficient construction and building materials: LCA, Eco-labelling and case studies. Cambridge, UK: Woodhead Publishing Limited Abington Hall; 2013. p. 624.

[92] Societé Generale. Chinese construction bubble - preparing for a potential burst. 2011 <http://pt.scribd.com/doc/58599536/ SocGenChinaConstruction>.

[93] KETs. High level expert group. Final report. 2009.

[94] Weinberger N, Jorissen J, Schipi J. Foresight on environmental technologies: options for the prioritisation of future research funding - lessons learned from the project "roadmap environmental technologies 2020+". J Clean Prod 2012;27:32-41.

[95] Pike Research. Energy efficient buildings: global outlook. 2011.

[96] Jelle B. Traditional, state-of-the-art and future thermal building insulation materials and solutions - properties, requirements and possibilities. Energy Build 2011;43:2549-63.

[97] Aegerter, Michel A, Leventis, Nicholas, Koebel, Matthias. (Eds.), Aerogels Handbook. Springer series advances in sol-gel derived materials and technologies. 1st ed., ISBN: 978-1-4419-7477-8, 2011.

[98] Buratti C, Moretti E. Glazing systems with silica aerogel for energy savings in buildings. Appl Energy 2012;98:396-403.

[99] Baetens R, Jelle B, Gustavsen A. Aerogel insulation for building applications: a state-of-the-art review. Energy Build 2011;43:761-9.

[100] Schultz J, Jensen K, Kristiansen F. Super insulating aerogel glazing. Sol Energy Mater Sol Cells 2005;89:275-85.

[101] Jelle BP, Hynd A, Gustavsen A, Arasteh D, Goudey H, Hart R. Fenestration of today and tomorrow: a state-of-the-art review and future research opportunities. Sol Energy Mater Sol Cells 2012;96:1-28.

[102] Hashimoto K, Irie H, Fujishima $\mathrm{A} \mathrm{TiO}_{2}$ photocatalysis: a historical overview and future prospects. Jpn J Appl Phys 2005;44:8269-85.

[103] He J, Hoyano A. A numerical simulation method for analyzing the therma improvement effect of super-hydrophilic photocatalyst-coated building surfaces with water film on the urban/built environment. Energy Build 2008:40:968-78.

[104] Kalaiselvam S, Parameshwaram R, Harikrishnan S. Analytical and experimental investigations of nanoparticles embedded phase change materials for cooling application in modern buildings. Renew Energy 2012:39:375-87.

[105] HLG KET. High level group on KETs. Thematica area, nanotechnology Nanotechnology: a sustainable basis for competitiveness and growth in Europe. 2010.

[106] Papaefthimiou S, Syrrakou E, Yianoulis P. Energy performance assessment of an electrochromic window. Thin Solid Films 2006;502:257-64.

[107] Yoshimura K, Yamada Y, Bao S, Tajima K, Okada M. Preparation and characterization of gasochromic switchable-mirror window with practical size. Sol Energy Mater Sol Cells 2009:2138-42.

[108] Baetens R, Jelle B, Gustavsen A. Properties, requirements and possibilities of smart windows for dynamic daylight and solar energy control in buildings: a state-of-the-art review. Sol Energy Mater Sol Cells 2010:94:87-105.

[109] Granqvist C-G. Switchable glazing technology for eco-efficient construction. in nanotechnology in eco-efficient construction. Materials, processes and applications, In: Pacheco-Torgal F, Diamanti V, Nazari A, Granqvist CG, editors. Cambridge, UK: Woodhead Publishing Limited Abington Hall; 2013. p. 236-69.

[110] Loonen R, Trcka M, Costola D, Hensen J. Climate adaptive building shells: state-of-the-art and future challenges. Renew Sustain Energy Rev 2013;25:483-93.

[111] Pike Research. Smart glass-electrochromic, suspended particle thermochromic, and liquid crystal glass technologies for architectural and transportation applications. Global Market Analysis and Forecasts. 2012. 